\title{
The adverse effects of inferior innovations
}

\author{
Joseph W. CHANG \\ University of Massachusetts, Dartmouth, MA, USA \\ joseph.chang@umassd.edu \\ D. Steven WHITE \\ University of Massachusetts, Dartmouth, MA, USA
}

\begin{abstract}
This research advances brand innovation research by examining the adverse effects of inferior innovative extensions on the brand innovability of own parent brands. Brand innovability conceptually consists of brand quality and innovativeness. The results reveal that radical and incremental inferior innovations exert asymmetric adverse effects on brand quality and innovability. For brand quality, inferior radical innovations exert more negative impacts on the quality of pioneer brands than on the quality of follower brands. However, inferior incremental innovations exert identical negative impacts on the quality of both pioneer and follower brands. For brand innovability, both inferior radical and incremental innovations exert more negative impacts on the innovability of pioneer brands than on the innovability of follower brands. In comparison, brand innovability is less susceptible than brand quality to inferior innovation information. The findings suggest that it is more justified to evaluate innovative brands with brand innovability, instead of brand quality, for two reasons. Firstly, brand innovability is more realistic than brand quality because brand innovability is more relevant than brand quality to profits. Secondly, brand innovability is inclusive of brand innovativeness, which ameliorates adverse effects when innovative extensions are inferior. The threat of inferior innovative extensions is less horrible than expectation if the adverse effects on the innovative brands are assessed with brand innovability, instead of brand quality. However, being innovative is like a double-edged sword. On the one hand, it helps generating more profits. On the other hand, it endangers innovative brands to be more susceptible to inferior innovative extensions. Therefore, for marketing implications, pioneer brands are more obliged than follower brands to ensure the success of radical innovations in order to avoid the possible adverse effects of inferior radical innovations. This research contributes brand innovation research by proposing the more relevant indicator of brand innovability to evaluate innovative brands.
\end{abstract}

Keywords: brand innovability, brand quality, brand innovativeness, extension innovativeness, cue-diagnosticity, adverse effect, brand extension.

Please cite the article as follows: Chang, J.W. and White, D.S. (2017), "The adverse effects of inferior innovations", Management and Marketing. Challenges for the Knowledge Society, Vol. 12, No. 3, pp. 361-375. DOI: 10.1515/mmcks-2017-0022.

\section{Introduction}

In innovation research, innovability is utilized to describe the capability to innovate (e.g., Dahlgaard-Park and Dahlgaard, 2010). Profiting firms (e.g., Google) are typically innovative companies with high innovability in inventing high-tech innovations (Jonash and Sommerlatte, 1999; Nedergaard and Gyrd-Jones, 2013), which are relevant to the increases of long-term performance, including the bottom line of firm income, the top-line of firm revenue, and the firm value in stock markets (Pauwels et al., 2004). Thus, in addition to brand quality, brand innovability has become an important indicator evaluating brand health. Moreover, extant research in brand 
evaluations has widely investigated the adverse effects of brand extensions (e.g., Google Glass) on own family brand names (e.g., Google), which are moderated by the characteristics of brands (e.g., Gurhan-Canli, 2003), brand extensions (e.g., Arslan and Altuna, 2010; Chang, 2002; Liao et al., 2015; Michel and Donthu, 2014; Pina et al., 2013), and perceivers (e.g., Salinas and Pérez, 2009). However, these studies mainly discuss the adverse impacts of regular extensions on regular brands specifically in the perspective of brand quality. Less is known about the adverse impacts of inferior innovations (as brand extensions) specifically on brand innovability.

Therefore, this research advances innovation research by examining the adverse effects of inferior innovations on the brand innovability of own family brands. Specifically, the study examines the moderations of extension innovativeness and brand innovability on the adverse effect of inferior innovations.

\section{Theoretical background Brand innovability}

In innovation research, the capability of innovation is discussed with various, but interchangeable, terminologies including innovability, capability to innovate (Dahlgaard-Park and Dahlgaard, 2010), innovation ability (Schreier et al., 2012), innovativeness capability (Luo and Bhattacharya 2006), and perceived innovativeness (Kunz et al., 2011). Specifically, Dahlgaard-Park and Dahlgaard (2010) create the terminology of innovability to represent the ability to innovate for the development of a system for assessing and improving technology development and innovations. The research scope is mainly from the perspectives of firms. Luo and Bhattacharya (2006) delineate that firms with low innovativeness capability are highly correlated with low customer satisfaction and market value. Kunz and colleagues (2011) uncover that perceived innovativeness affects consumer loyalty via the two processing routes of functional-cognitive and affective-experiential routes. Moreover, Schreier and colleagues (2012) depict that common design by users enhances consumers' perceptions of innovation ability. While similar concepts about innovability were utilized to examine innovation research questions, none of them investigates the adverse effects of inferior innovations on brand innovability.

To be consistent, this study adopts the shortest terminology of innovability for its novelty and uniqueness and to differentiate it from the innovativeness of innovative brands and extensions. Moreover, based on the extant research, innovability can be more comprehensively defined as the ability to generate new and useful products/services innovatively (Brown and Dacin, 1997; Dahlgaard-Park and Dahlgaard, 2010; Luo and Bhattacharya, 2006; Rust et al., 2002; Schreier et al., 2012; Zeithaml, 2000).

\section{The impacts of inferior innovations on brand innovability}

In innovation research, brand (or corporate) abilities consist of brand quality and innovability, which refer to a brand's (or firm's) ability to improve existing brand quality and generate new innovations (Luo and Bhattaoharya, 2006; Rust et al., 2002; Zeithaml, 2000). Thus, brand quality is assumed to be affected by extension quality, whereas brand innovability is assumed to be affected by extension innovativeness.

However, innovability is not just about the creation of creative and novel innovations (Kunz et al., 2011). The created innovations have to be (of good quality to be) useful in order to survive and exert market impacts, which is the third key 
point of an innovative brand (Kunz et al., 2011; Schreier et al., 2012). A brand with the characteristics of novelty and creativity is insufficient to be a high-innovability brand if its innovations are of low quality and thus useless. As a result, innovability is relevant to, and affected by, innovation quality, in addition to extension innovativeness. The inference suggests that consumers' judgment about brand innovability is jointly affected by extension innovativeness and quality. Operationally, the first three measures of the brand innovability scale (Schreier et al., 2012; see the Appendix) capture the relevance between brand innovability and extension quality (i.e., "In my opinion, the innovation ability of this company is high/low," "In my opinion, the innovation ability of this company is weak/strong," and "In my opinion, the innovation ability of this company is poor/excellent").

Moreover, brands are characterized as pioneers, opportunists, and followers on the basis of innovability, whereas new innovations are classified as incremental, substantial (or breakthrough), and radical (or transformational) offerings on the basis of product innovativeness (e.g., newness, value-add) (Crawford, 2014). Specifically, pioneers are high in innovability and commit to radical innovations, which create new industries and transform the way people live and work. In contrast, followers are low in innovability and engage in incremental innovations, which are continuously improved products or technological processes. Thus, the discussion about the adverse effects of new innovations on brands involves the interplay of brand innovability and extension innovativeness. The interplay consists of four conditions: the adverse impacts of (a) radical innovations on pioneer brands; (b) radical innovations on follower brands; (c) incremental innovations on pioneer brands; and (d) incremental innovations on follower brands.

Following the discussion about the impacts of inferior innovations, cuediagnosticity theory (Skowronski and Carlston, 1987, 1989) is utilized to conceptualize the research hypotheses for the four conditions as delineated in the ensuing sections.

\section{The cue-diagnosticity theory}

In social categorization, cue-diagnosticity theory depicts that impressions formation about a group is a diagnosticity-based categorization process integrating positivity and negativity biases (Skowronski and Carlston, 1987, 1989). The judgment of diagnosticity is determined by comparing the perceived probability of occurrences. A diagnostic cue (e.g., cheating at exams) is salient information suggesting one category (e.g., dishonest people) over an alternative one (e.g., honest people). A cue (e.g., cheating at exams) is diagnostic if it induces a higher perceived probability that an object belongs to one category (e.g., dishonest people) and a lower perceived probability that the object belongs to an alternative category (e.g., honest people). In other words, a cue is diagnostic if the difference of the perceived probabilities of a target category and an alternative category is significant. Specifically, positivity biases occur if a positive cue (e.g., winning an International Mathematical Olympiad [IMO] gold medal) suggests a higher perceived probability for the target positive category (e.g., intelligent people) than for the alternative negative category (e.g., unintelligent people). In contrast, negativity biases occur if a negative cue (e.g., cheating at exams) suggests a higher perceived probability for the target negative category (e.g., dishonest people) than for the alternative positive category (e.g., honest people). 
Moreover, extreme diagnostic cues exert more contrast on the perceived probabilities between the target and alternative categories. As a result, extreme diagnostic cues receive more weight, and generate more impact, on the impression formation of a subject in the target category (e.g., Anderson, 1981). Specifically, an extreme and positive diagnostic cue (e.g., winning an IMO gold medal) is more extreme to, and generates stronger positive impacts on, the member of the negative category (e.g., unintelligent people), yielding extremity and positivity biases (Anderson, 1981; Fiske, 1980; Kanouse and Hanson, 1972; Skowronski and Carlston, 1987, 1989; Wyer, 1974). In contrast, an extreme and negative diagnostic cue (e.g., cheating at exams) is more extreme to, and generates more negative impacts on, the member of the positive category (e.g., honest people), yielding extremity and negativity biases. Based on the cue-diagnosticity theory (Skowronski and Carlston, 1987, 1989), the impacts of inferior innovations on brand quality and innovability are discussed separately as follows.

\section{The impacts on brand quality}

In general, pioneer brands typically consist of radical and incremental brands, whereas follower brands typically consist of incremental brands only. Pioneer brands are more capable in developing radical innovations. Given the experience in launching innovations, the probability of a radical innovation to be inferior is relatively lower for a pioneer brand (e.g., 1/10) and is relatively higher for a follower brand (e.g., 9/10). Thus, inferior radical innovation information is an extreme diagnostic cue as the difference in probabilities is very significant (e.g., | 1/10 - 9/10 | $=8 / 10$ ). The inferior radical innovation information indicates of the target category of follower brands and weakens the brand quality of pioneer brands more than the brand quality of follower brands (e.g., -8/10 vs. -1/10) (Anderson, 1981). Thus,

H1a. Negative radical innovations weaken pioneer brand quality more than follower brand quality.

Moreover, given the experience in launching innovations, the probabilities for the incremental innovations to be inferior are similar for both pioneer and follower brands (e.g., 2/10 vs. 3/10). As a result, inferior incremental innovation information is a non-diagnostic cue as the difference of probabilities is insignificant (e.g., | 2/10 $3 / 10 \mid=1 / 10$ ). The inferior incremental innovation information indicates of either a pioneer or follower brand and identically weakens the quality of pioneer and follower brands (e.g., -8/10 vs. -7/10) (Anderson, 1981). Therefore,

$\mathrm{H} 1 \mathrm{~b}$. Negative incremental innovations identically weaken the quality of pioneer and follower brands.

\section{The impacts on brand innovability.}

As brand innovability is affected by extension innovativeness and quality (Kunz et al., 2011; Schreier et al., 2012), the diagnosticity of inferior innovations on brand innovability can be captured by averaging the individual diagnosticities of extension quality and innovativeness.

As pioneer brands are more likely to launch radical innovations, the probability of launching a radical innovation is high and expected for a pioneer brand (e.g., 9/10). In contrast, as follower brands are less likely to launch radical innovations, the probability of launching a radical innovation is low and unexpected 
for a follower brand (e.g., 1/10). Thus, the launch of a radical innovation is a diagnostic cue for brand innovativeness as the difference of probabilities is significant (e.g., $|9 / 10-1 / 10|=8 / 10$ ). The radical innovation information slightly affects the brand innovability of the pioneer brand specifically in brand innovativeness (e.g., 1/10). In contrast, the radical innovation information largely enhances the brand innovability of the follower brand specifically in brand innovativeness (e.g., 9/10).

Moreover, the enhancement in brand innovativeness ameliorates the weakening of inferior radical innovations on the quality of pioneer and follower brands (e.g., -8/10 vs. -1/10, discussed in the earlier part of this section). As a result, inferior radical innovations weaken the innovability of pioneer brands more than the innovability of follower brands (e.g., $[-8 / 10+1 / 10] / 2=-.35$ vs. $[-1 / 10+9 / 10] / 2$ $=.4$ ). In other words, inferior radical innovation information is a diagnostic cue of brand innovability (e.g., $|-.35-.4|=.75$ ), which indicates of the target category of low-innovability brands. Thus,

H2a. Inferior radical innovations weaken the innovability of pioneer brands more than the innovability of follower brands.

While both pioneer and follower brands are capable of launching incremental innovations, pioneer brands are more likely to launch radical innovations, whereas follower brands are more likely to launch incremental innovations. As a result, the probability of launching an incremental innovation is relatively lower for a pioneer brand (e.g., 1/9) and is relatively higher for a follower brand (e.g., 9/10). Thus, the launch of an incremental innovation is a diagnostic cue for brand innovativeness as the difference of probabilities is significant (e.g., $|1 / 10-9 / 10|=8 / 10$ ). The incremental innovation information indicates of the target category of follower brands. The diagnostic cue weakens the brand innovativeness of pioneer brands (e.g., -8/10) more than the brand innovativeness of follower brands (e.g., -1/10).

Moreover, as brand innovability consists of brand innovativeness and quality (Kunz et al., 2011; Schreier et al., 2012), the weakening in brand innovativeness aggravates the weakening of inferior incremental innovations on the quality of pioneer and follower brands (e.g., -8/10 vs. $-7 / 10$, discussed in the earlier part of this section). As a result, inferior incremental innovations weaken the innovability of pioneer brands more than the innovability of follower brands (e.g., [-8/10 - 8/10] / 2 $=-.8$ vs. $[-1 / 10-7 / 10] / 2=-.4)$. In other words, inferior incremental innovation information is a moderate diagnostic cue of brand innovability (e.g., $|-.8-(-.4)|=.4$ ) indicating of the target category of follower brands. Therefore,

H2b. Inferior incremental innovations weaken the innovability of pioneer brands more than the innovability of follower brands.

In comparison, the impacts of inferior innovations on brand innovability are affected by both the innovativeness and quality of innovations (Kunz et al., 2011; Schreier et al., 2012), whereas the impacts on brand quality are mainly determined by innovation quality (Luo and Bhattaoharya, 2006; Rust et al., 2002; Zeithaml, 2000). Given that, the negative impacts of inferior innovations on brand innovability get the chance to be counterbalanced by the positive impacts of extension innovativeness. As a result, brand innovability appears less saliently weakened than brand quality by inferior innovations. However, the counterbalance effect of extension innovativeness 
diminishes when the level of extension innovativeness is lower than the level of brand innovativeness (e.g., pioneer brands with inferior incremental innovations). Under the situation, the negative impacts of inferior innovations on brand quality and innovability turn to be indifferent. Thus,

H3. Inferior innovation information weakens brand quality more than brand innovability, except the condition when the brand is a pioneer brand and the inferior extension is an incremental innovation.

\section{Experimental study \\ Method}

In line with previous research and for the ease of manipulation (Loken and RoedderJohn, 1993), the fictitious names of Appsung and Appsung V6 were created to represent the innovative brand and new innovative extension. The Appsung brand name was based on the two major smartphone makers of Apple and Samsung for the ease of high quality associations. The experimental treatments of the Appsung brand and Appsung V6 extension were cultivated with PC Home assessments. The pioneer and follower Appsung brands were portrayed as a smartphone pioneer (i.e., "pioneering a few patented breakthrough innovations;" see the Appendix) and follower (i.e., "engaging in imitation and light revision;" see the Appendix), respectively. The high- and low-innovativeness Appsung V6 were delineated as a radical (i.e., "with wireless charging and hyper processer;" see the Appendix) and incremental (i.e., "with higher display resolution;" see the Appendix) innovations, respectively. There are internal and external reasons causing the failure of an innovation. This research specifies the internal reason of inferior innovation with low-quality.

The data were collected online via the Amazon Mechanical Turk (www.mturk.com) with Qualtrics questionnaires (www.qualtrics.com). One hundred and sixty-five smartphone users residing in the USA $\left(M_{\text {age }}=31.93,65\right.$ females, 100 males) were randomly assigned to the 2 (brand innovability: pioneer vs. follower) $\mathrm{x} 2$ (extension innovativeness: radical vs. incremental) between-subjects factorial design. The participants were informed that the purpose of study was to investigate consumer opinions about smartphones. The participants started with reading the PC Home assessment about the Appsung brand and rating the prior quality and innovability of the Appsung brand, followed by a series of rating tasks including the quality and innovativeness of the newly launched Appsung V6 and the posterior quality and innovability of the Appsung brand. Prior and posterior brand quality was captured with the three-item brand attitude measure of quality, favorability, and desirability (e.g., Kempf and Smith, 1998). The brand innovability was captured with the seven-item innovation ability measures (Luo and Bhattaoharya, 2006; Rindfleisch and Moorman, 2001; Schreier et al., 2012; see the Appendix). Moreover, the extension innovativeness was identified with the 9-item product innovativeness measure (Lee and O'Connor, 2003; see the Appendix).

\section{Results}

Manipulation checks

As scale reliability analyses on the multiple-item measures yielded high reliabilities $\left(\alpha_{s} \geq .93\right)$, the brand quality, brand innovability, extension innovativeness, and extension quality indices were formulated by averaging the scores of each set of Vol. 12, No. 3, Autumn, pp. 361-375, ISSN 1842-0206 | Management \& Marketing. Challenges for the Knowledge Society 
multiple items. One-way ANOVAs on these indices revealed that (a) the innovability of the pioneer Appsung brand was higher than the innovability of the follower Appsung brand $\left(M_{\text {pioneer }}=5.92, M_{\text {follower }}=3.89, F(1,163)=111.43, p<.001\right) ;($ b) the innovativeness of the radical Appsung V6 was higher than the innovativeness of the incremental Appsung V6 $\left(M_{\text {radical }}=4.71, M_{\text {incremental }}=3.83, F(1,163)=21.40, p<.001\right)$; and (c) both the inferior radical and incremental Appsung V6 extensions were low quality $\left(M_{\text {radical }}=2.24, M_{\text {neutral }}=4, t(83)=12,18, p<.001 ; M_{\text {incremental }}=3.24, M_{\text {neutral }}=4\right.$, $t(80)=3.77, p<.001)$. Thus, the independent variables of brand innovability, extension innovativeness, and extension quality were properly manipulated. Specifically, the levels of brand innovability and quality were carefully crafted as either moderately high or low to prevent the bias of ceiling effect. Moreover, brand quality and innovability change indices were developed to verify the effects of inferior innovations on brand quality and innovability. The indices were captured by comparing their prior and posterior measures.

\section{Test of hypotheses}

\section{Impacts on perceived quality}

Two-way ANOVA on the quality change index is used to test the main effect of innovability $(F(1,161)=7.55, p<.01)$ and marginal main effect of extension innovativeness $(F(1,161)=2.97, p=.09)$ (see Figure 1 and Table 1). Specifically, simple-effects tests revealed that the perceived quality of the pioneer Appsung was more significantly weakened then the follower Appsung by the inferior radical Appsung V6 $\left(M_{\text {pioneer }}=-2.76, M_{\text {follower }}=-1.81, F(1,161)=6.89, p<.01\right)$. However, the inferior incremental Appsung V6 instigated identical negative impacts on the quality of both pioneer and follower Appsung brands $\left(M_{\text {pioneer }}=-2.07, M_{\text {follower }}=-1.60, F(1\right.$, $161)=1.62, p>.10)$. The results indicated that inferior radical innovations were more detrimental to the quality of pioneer brands, whereas inferior incremental innovations instigated identical negative impacts on both pioneer and follower brands. Therefore, hypothesis 1 was supported.

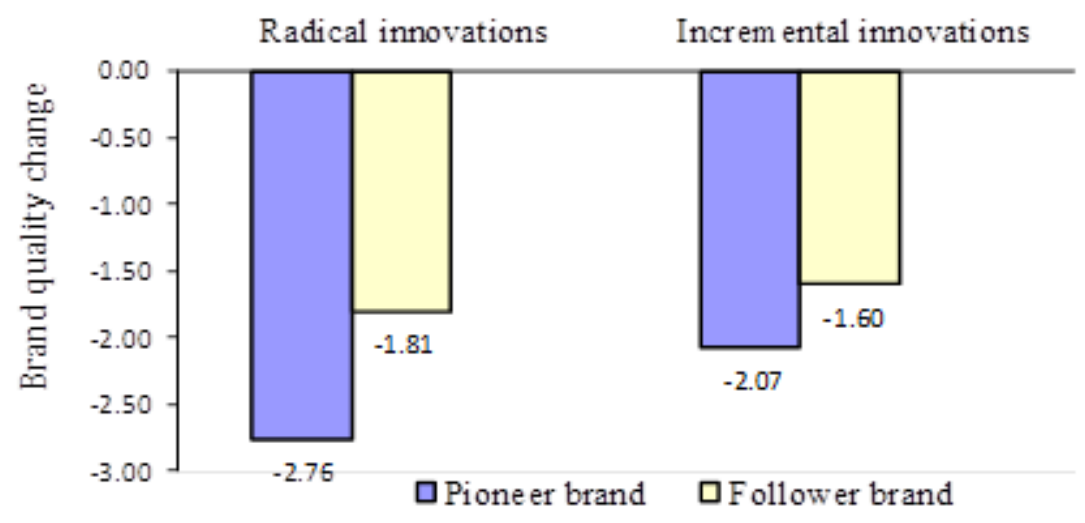

Figure 1. The Adverse Effects of Inferior Innovations on Brand Quality

Source: Author's own research. 
Table 1. Summary: means and standard deviations

\begin{tabular}{|c|c|c|c|c|c|}
\hline \multirow[b]{3}{*}{ Innovation } & \multicolumn{2}{|c|}{ Brand } & \multirow[t]{2}{*}{$\begin{array}{c}\text { Comparison } \\
\text { (F value) }\end{array}$} & \multirow[t]{2}{*}{ Hypo. } & \multirow[t]{2}{*}{ Results } \\
\hline & Pioneer & Follower & & & \\
\hline & \multicolumn{2}{|c|}{ Quality change index } & & & \\
\hline Radical & $-2.76(1.82)$ & $-1.81(1.80)$ & $6.89^{* *}$ & H1a & Supported \\
\hline \multirow[t]{2}{*}{ Incremental } & $-2.07(1.68)$ & $-1.60(1.33)$ & 1.62 & $\mathrm{H} 1 \mathrm{~b}$ & Supported \\
\hline & \multicolumn{2}{|c|}{ Innovability change index } & & & \\
\hline Radical & $-1.61(1.27)$ & $-.72(1.53)$ & $8.59^{* *}$ & $\mathrm{H} 2 \mathrm{a}$ & Supported \\
\hline Incremental & $-2.18(1.67)$ & $-.77(.97)$ & $20.91^{* * *}$ & $\mathrm{H} 2 \mathrm{~b}$ & Supported \\
\hline \multirow[b]{2}{*}{ Brand } & \multicolumn{2}{|c|}{ Change of Index } & Comparison & Нуро. & Results \\
\hline & Quality change & Innovability change & (t value) & & \\
\hline \multicolumn{6}{|l|}{ Pioneer } \\
\hline Radical & $-2.76(1.82)$ & $-1.61(1.27)$ & $-4.70^{* * *}$ & H3 & Supported \\
\hline Incremental & $-2.07(1.68)$ & $-2.18(1.67)$ & .49 & H3 & Supported \\
\hline \multicolumn{6}{|l|}{ Follower } \\
\hline Radical & $-1.81(1.80)$ & $-.72(1.53)$ & $-5.34^{* * *}$ & H3 & Supported \\
\hline Incremental & $-1.60(1.33)$ & $-.77(.97)$ & $-4.50^{* * *}$ & H3 & Supported \\
\hline
\end{tabular}

Source: Author's own research.

\section{Impacts on brand innovability}

Two-way ANOVA on the innovability change index yielded the main effect of innovability $(F(1,161)=28.27, p<.001)$, which suggested that the inferior Appsung V6 instigated unparalleled impacts on the innovability of pioneer and follower Appsung brands. Specifically, simple-effects tests revealed that the innovability of the pioneer Appsung was more significantly weakened than the follower Appsung by both the radical and incremental Appsung V6 extensions $\left(M_{\text {pioneer }}=-1.61, M_{\text {incremental }}=\right.$ $-.72, F(1,161)=8.59, p<.01 ; M_{\text {pioneer }}=-2.18, M_{\text {incremental }}=-.77, F(1,161)=20.91, p$ $<.001$; see Figure 2). The results indicated that both inferior radical and incremental innovations instigated more negative impacts on pioneer brand innovability than follower brand innovability. Thus, hypothesis 2 was supported.

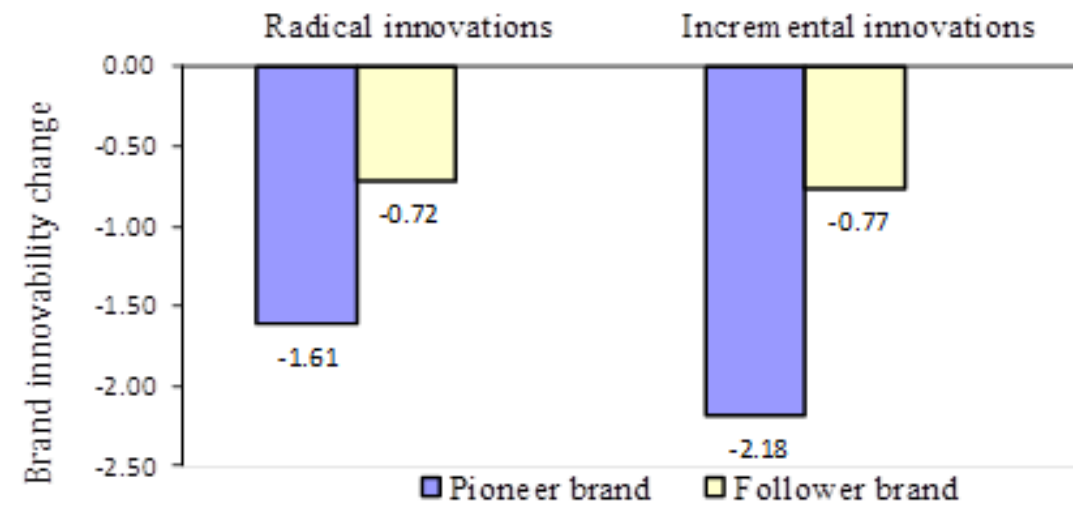

Figure 2. The Adverse Effects of Inferior Innovations on Brand Innovability

Source: Author's own research. 
The susceptibility of brand innovability and quality

Pair-samples t-tests revealed that the brand innovability of Appsung was less significantly weakened than the brand quality of Appsung by the Appsung V6 $\left(M_{\text {innovability }}=-1.61, M_{\text {quality }}=-2.76, t(40)=-4.70, p<.001 ; M_{\text {innovability }}=-.72, M_{\text {quality }}=-\right.$ $1.81, t(42)=-5.34, p<.001 ; M_{\text {innovability }}=-.77, M_{\text {quality }}=-1.60, t(39)=-4.50, p<.001$; see Figures 3 and 4), except the condition when the Appsung was a pioneer brand and the inferior Appsung V6 was an incremental innovation. Both brand quality and innovability were identically weakened $\left(M_{\text {innovability }}=-2.18, M_{\text {quality }}=-2.07, t(40)=.49\right.$, $p>.05$; see Figure 3). Therefore, hypothesis 3 was confirmed.

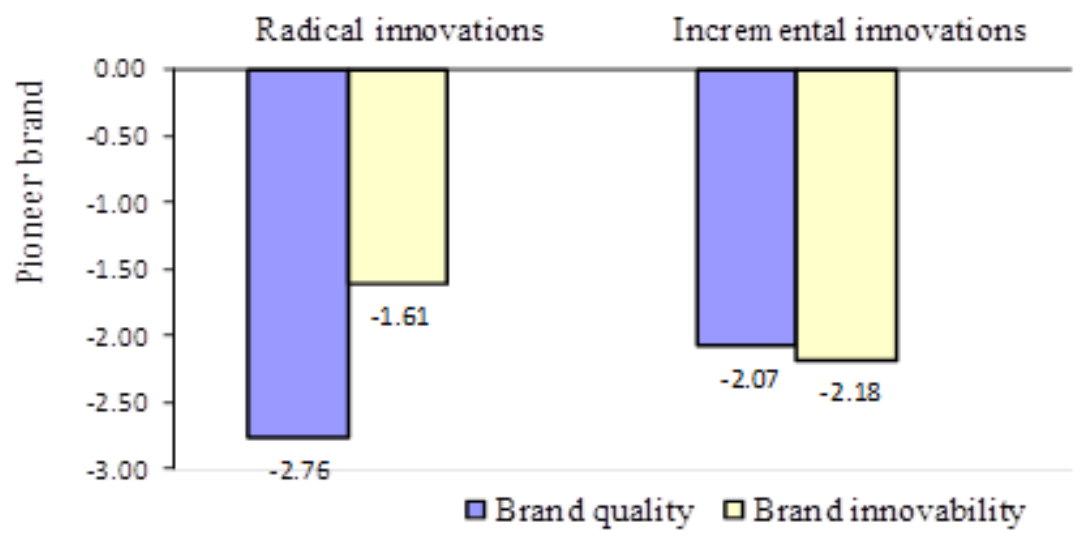

Figure 3. The Vulnerability of Brand Quality and Innovability toward the Inferior Innovation of the Pioneer Brand

Source: Author's own research.

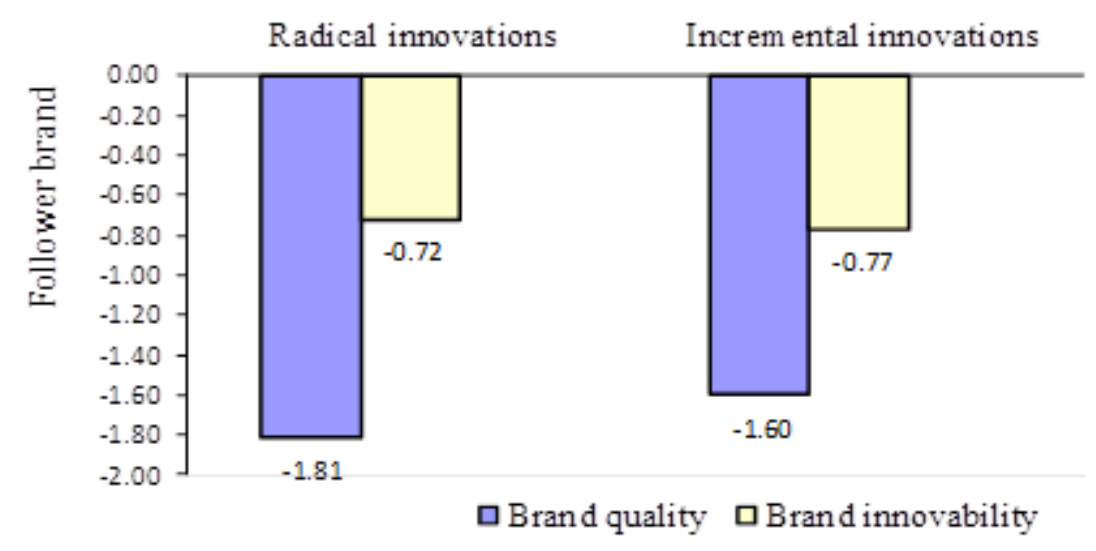

Figure 4. The Vulnerability of Brand Quality and Innovability toward the Inferior Innovation of the Follower Brand

Source: Author's own research.

In conclusion, inferior radical and incremental innovations yield unparalleled impact patterns on the brand quality and innovability of pioneer and follower brands. In terms of brand quality, inferior radical innovations instigate more negative impacts on the quality of pioneer brands than on the quality of follower brands. However, inferior incremental innovations instigate identical negative impacts on the 
quality of both pioneer and follower brands. In terms of brand innovability, both inferior radical and incremental innovations instigate more negative impacts on the innovability of pioneer brands than on the innovability of follower brands. In comparison, brand innovability is less vulnerable than brand quality to inferior innovations, except the condition when the brand is a pioneer brand and the inferior extension is an incremental innovation. Both the brand quality and innovability of pioneer brands are identically weakened by inferior incremental innovations.

\section{Discussion and conclusions}

This article advances innovation research by examining the adverse effects of inferior innovations on brand quality and innovability. The adverse effects of inferior innovations on the brand innovability and brand quality of pioneer and follower brands are asymmetric. The research contributes innovation research by proposing the more relevant indicator of brand innovability for evaluating brand health. Based on the research findings, the theoretical and managerial implications and the limitations and future research are discussed as follows.

\section{Theoretical implications}

This study reveals that radical and incremental innovations exert asymmetric adverse effects on pioneer and follower brands. Negative radical innovation information weakens pioneer brand quality more than follower brand quality, whereas negative incremental innovation information identically weakens the quality of pioneer and follower brands. Both inferior radical and incremental innovations weaken the innovability of pioneer brands more than the innovability of follower brands. Furthermore, this study reveals that inferior innovation information weakens brand quality more than brand innovability, except the condition when the brand is a pioneer brand and the inferior extension is an incremental innovation.

In conclusion, the cue-diagnosticity (Skowronski and Carlston, 1987, 1989) perfectly interpret the research questions. Moreover, in brand research, Michel and Donthu (2014) utilize the central and peripheral brand association concepts to discuss the adverse effects of brand extensions with consistent and inconsistent associations to parent brands. They depict that, if the brand extension is inconsistent with the central brand associations, the adverse effects on brand attitudes are more negative than if the brand extension is inconsistent with the peripheral brand association. The theory is confirmed by the results of this research if highinnovability is assumed as the central brand associations and the inferior innovation information is assumed as an inconsistent association to the central brand associations. Conversely, low-innovability is assumed as the peripheral brand associations and the inferior innovation information is assumed as an inconsistent association to the peripheral brand associations.

Furthermore, extant research in extension adverse effects indicate that negative typical extension information is a diagnostic cue indicating of a low quality brand. The negative extension information weakens a high-quality brand more than a low-quality brands (Ahluwalia and Gurhan-Canli, 2000), which supports the result of this research that inferior radical innovations weaken the quality of pioneer brands more than follower brands. An inferior radical innovation is a typical extension of a pioneer brand with relatively higher brand quality than a follower brand. 


\section{Managerial implications}

The research findings reveal that the impacts of inferior innovations on own family brands are moderated by brand innovability and extension innovativeness. The impacts of inferior radical and incremental extensions on the innovability and quality of pioneer and follower brands are asymmetric. In general, inferior radical innovations are more detrimental to both the innovability and quality of highinnovability brands, whereas inferior incremental innovations are only more detrimental to the innovability of pioneer brands. The findings suggest that inferior new innovations are more detrimental to both the quality and innovability of pioneer brands than follower brands. As a result, inferior high-tech innovations (e.g., Google Glass) are more detrimental to both the quality and innovability of higher innovative brands (e.g., Google vs. Sharp). In confronting with the possible failures of radical innovations (e.g., Glass), pioneer brands (e.g., Google) are more obliged to ensure the success of the radical innovations (e.g., Glass) because the adverse effects of inferior radical innovations are more detrimental to pioneer brands on both brand quality and innovability.

In conclusion, the research findings suggest that it is more justified to evaluate innovative brands with brand innovability, instead of brand quality, for two reasons. Firstly, brand innovability is more realistic than brand quality because brand innovability is more relevant than brand quality to profits. Secondly, brand innovability is inclusive of brand innovativeness, which ameliorates adverse effects when innovative extensions are inferior. The threat of inferior innovative extensions is less horrible than expectation if the adverse effects on the innovative brands are assessed with brand innovability, instead of brand quality. However, being innovative is like a double-edged sword. On the one hand, it helps generating more profits. On the other hand, it endangers innovative brands to be more susceptible to inferior innovative extensions.

\section{Limitations and future research}

Extant research in innovation documents that consumer innovativeness is relevant to the evaluations of brand extensions (Salinas and Pérez, 2009). Specifically, highinnovativeness consumers prefer, and have higher adoption rates for, high-tech extensions than low-innovativeness consumers (e.g., Bartels and Reinders, 2011; Tellis et al., 2009). However, the previous research mainly discusses the relevance between consumer innovativeness and the evaluation and adoption of extensions. Less is known about the moderation of consumer innovativeness on the adverse effects of inferior innovations from both the perspectives of brand innovability and quality. Therefore, future research should be conducted to verify the moderation of consumer innovativeness on the adverse effects of inferior innovations.

Additionally, in line with previous research, this study utilized fictitious brands as experimental treatments for the ease of manipulation. Future research may utilize real brand names to compare the results based on fictitious and real brand names. Research results based on real brand names are more plausible for the generalization of research findings. 


\section{References}

Ahluwalia, R. and Gurhan-Canli, Z. (2000), "The effects of extensions on the brand name: An accessibility-diagnosticity perspective", Journal of Consumer Research, Vol. 27, No. 3, pp. 371-381.

Anderson, N.H. (1981), Foundations of information integration theory, Academic Press: New York, NY.

Arslan, F.M. and Altuna, O.K. (2010),"The effect of brand extensions on product brand image", Journal of Product \& Brand Management, Vol. 19, No.3, pp. 170 - 180.

Bartels, J. and Reinders, M.J. (2011), "Consumer innovativeness and its correlates: a propositional inventory for future research," Journal of Business Research, Vol. 64, No. 6, pp. 601-609.

Brown, T.J. and Dacin, P.A. (1997), "The company and the product: Corporate associations and consumer product responses", Journal of Marketing, Vol. 61, No. 1, pp. 68-84.

Chang, J.W. (2002), "Will a family brand image be diluted by an unfavorable brand extension? A brand trial-based approach", Advances in Consumer Research, Vol. 29, pp. 299-304.

Crawford, C.M. (2014), New Product Management, 11 ${ }^{\text {th }}$ ed., Irwin/McGraw-Hill: New York, NY.

Dahlgaard Park, S.-M. and Dahlgaard, J.J. (2010), "Organizational learnability and innovability: A system for assessing, diagnosing and improving innovations", International Journal of Quality and Service Sciences, Vol. 2, No. 2, pp. 153-174.

Fiske, Susan T. (1980), "Attention and weight in person perception: The impact of negative and extreme behavior", Journal of Personality and Social Psychology, Vol. 38, No. 6, pp. 889-906.

Gurhan-Canli, Z. (2003), "The effect of expected variability of product quality and attribute uniqueness on brand evaluations", Journal of Consumer Research, Vol. 30, No. 1, pp. 105-114.

Jonash, R. and Sommerlatte, T. (1999), The Innovation Premium, Perseus: Reading, MA.

Kanouse, D.E. and Hanson, L.R. (1972), Negativity in Evaluations, General Learning Press: New York, NY.

Kempf, D. S. and Smith, R. E. (1998), "Consumer processing of product trial and the influence of prior advertising: A structural modeling approach", Journal of Marketing Research, Vol. 35, No. 3, pp. 325-338.

Kunz, W., Schmitt, B. and Meyer, A. (2011), "How does perceived firm innovativeness affect the consumer?", Journal of Business Research, Vol. 64, No. 8, pp. 816-822.

Lee, Y. and O'Connor, G. (2003), "New product launch strategy for network effect products", Journal of the Academy of Marketing Science, Vol. 31, No. 3, pp. 241255.

Liao, S., Chou, C.Y. and Lin, T.H. (2015), "Adverse behavioral and relational consequences of service innovation failure", Journal of Business Research, Vol. 68, No. 4, pp. 834-839.

Loken, B. and Roedder-John, D. (1993), "Diluting brand beliefs: When do extensions have a negative impact?", Journal of Marketing, Vol. 57, No. 3, pp. 71-84.

Luo, X. and Bhattacharya, C.B. (2006), "Corporate social responsibility, customer satisfaction, and market value", Journal of Marketing, Vol. 70, No. 4, pp. 1-18. 
Michel, G. and Donthu, N. (2014), "Why negative brand extension evaluations do not always negatively affect the brand: The role of central and peripheral brand associations", Journal of Business Research, Vol. 67, No. 12, pp. 2611-2619.

Nedergaard, N. and Gyrd-Jones, R. (2013), "Sustainable brand-based innovation: The role of corporate brands in driving sustainable innovation", Journal of Brand Management, Vol. 20, No. 9, pp. 762-778.

Pauwels, K., Silva-Risso, J., Srinivasan, S. and Hanssens, D.M. (2004), "New products, sales promotions, and firm value: The case of the automobile industry", Journal of Marketing, Vol. 68, No. 4, pp. 142-156.

Pina, J.M., Riley, F.D. and Lomax, W. (2013), "Generalizing spillover effects of goods and service brand extensions: A meta-analysis approach", Journal of Business Research, Vol. 66, No. 9, pp. 1411-1419.

Rindfleisch, A. and Moorman, C. (2001), "The acquisition and utilization of information in new product alliances: a strength-of-ties perspective", Journal of Marketing, Vol. 65, No. 2, pp. 1-18.

Rust, R., Moorman, C. and Dickson, P.R. (2002), "Getting return on quality: Cost reduction, revenue expansion, or both?", Journal of Marketing, Vol. 66, No. 4, pp. 7-24.

Salinas, E.M. and Pérez, J.M.P. (2009), "Modeling the brand extensions' influence on brand image”, Journal of Business Research, Vol. 62, No. 1, pp. 50-60.

Schreier, M., Fuchs, C. and Dahl, D.W. (2012), "The innovation effect of user design: exploring consumers' innovation perceptions of firms selling products designed by users", Journal of Marketing, Vol. 76, No. 5, pp. 18-32.

Skowronski, J.J. and Carlston, D.E. (1987), "Social judgment and social memory: The role of cue diagnosticity in negativity, positivity, and extremity biases", Journal of Personality and Social Psychology, Vol. 52, No. 4, pp. 689-699.

Skowronski, J.J. and Carlston, D.E. (1989), "Negativity and extremity biases in impression formation: A review of explanations", Psychological Bulletin, Vol. 105, No. 1, pp. 131-142.

Tellis, G. J., Yin, E. and Bell, S. (2009), "Global consumer innovativeness: Crosscountry differences and demographic commonalities", Journal of International Marketing, Vol. 17, No. 2, pp. 1-22.

Wyer, R.S. (1974), Cognitive organization and change: An information-processing approach, Lawrence Erlbaum Associates: Hillsdale, NJ.

Zeithaml, V.A. (2000), "Service quality, profitability, and the economic worth of customers: What we know and what we need to learn", Journal of the Academy of Marketing Science, Vol. 28 No. 1, pp. 67-85.

\section{Appendix}

\section{Experimental treatments}

\section{Pioneer brand}

"Appsung is a leading high-tech brand in the smartphone market. The brand has pioneered a few patented breakthrough innovations of smartphone operating system and physical feature, including larger and better displays, faster video processors, slimmer and durable batteries, and faster and more sensitive cameras. The patented Appsung operating system, supporting third-party applications, is marvelously stable and user-friendly and has become the dominating platform in the smartphone market." -- Smartphone experts of PC Home 


\section{Follower brand}

"The Appsung smartphone company is a fast-follower who adepts at imitating and revising existing breakthrough innovations in product and process technologies invented by leading smartphone companies. Appsung focuses on cost-downs for the markets of less-developed countries and the late-majority of consumers adopting new innovations later, rather than the users of early adopters targeted by leading companies. Appsung has several light improvements in the smartphone features of displays, video processors, batteries, and cameras, while falls short in breakthrough innovations either for the smartphone operating system or physical components. Appsung smartphones adopt the most popular operating system invented by a leading smartphone company." -- Smartphone experts of PC Home

\section{Inferior Radical Innovation}

"The performance of the featured breakthrough innovations was surprisingly unstable and inefficient, which was disappointing.

Wireless charging. The wireless charging device fell short in capturing and connecting the wireless signals of Wi-Fi and internet for battery charging, which induced an unusual long full recharging of about 10 hours. Moreover, the wireless charging obviously heated up the device and incurred a slower operating system.

Hyper Processor. The configuration and operation of the hyper video processor for gaming and movies was very unstable. Games and movies got stuck with the processor easily. In comparison, the processing speed was only $30 \%$, rather than four times, faster than regular processors. Moreover, the unstable hyper processor consumed additional battery power and resulted in a much shorter battery life.

The two featured breakthrough innovations had consequently turned the smartphone experience into a nightmare. Given the inferior offer of product benefits, the Appsung V6 clearly falls short compared to its rivals and is overpriced." Smartphone experts of PC Home

\section{Inferior Incremental Innovation}

"The Appsung V6 is supposed to be the higher-end variant of Appsung. However, the featured $1920 \times 1080$ full HD screen does not make the display look better. If this is the best that Appsung has to offer in terms of innovation, then, it is safe to say that any of rivals' Android flagships blow the Appsung devices out of the water. In terms of specs, features, and price, it's hard to find a single aspect of the new Appsung flagship that is either powerful or innovative. The Appsung V6 flagship falls short compared to Android rivals. As a result, the new Appsung V6 is overpriced and overrated." - Smartphone experts of PC Home

\section{Measurement items}

Product Innovativeness: (Lee and O'Connor, 2003)

(1) The technology this product incorporates was new to me

(2) The benefits this product offers were new to me.

(3) The product features are novel/unique to me.

(4) This product introduced many completely new features to the market

(5) This product offers dramatic improvements to existing product features

(6) The knowledge required to use this product was new to me 
(7) I need to learn how to use this new product.

(8) I tend to resist adopting this new product.

(9) I needed to change my behavior in order to adopt this product.

Brand Innovability: (Schreier et al., 2012)

(1) In my opinion, the innovation ability of this company is high/low.

(2) In my opinion, the innovation ability of this company is weak/strong.

(3) In my opinion, the innovation ability of this company is poor/excellent.

(4) In my opinion, this company has the ability to develop really innovative new products.

(5) In my opinion, this company is in the position to derive very original product ideas.

(6) In my opinion, this company has a large potential to foster creativity.

(7) In my opinion, this company can create very interesting new products. 